\section{References}

${ }^{1}$ Myers GB, Klein HA, Hiratzka T. Correlations of electrocardiographic and pathologic findings in anteroposterior infarction. Am Heart $\mathcal{f}$ $1949 ; 37: 205-36$.

2 Marriott HJL. Myocardial infarction. In: Marriott HJL, ed. Practical electrocardiography. Baltimore: Williams and Wilkins, 1977:232-55.

${ }^{3}$ Shah TK, Pichler M, Berman DS, et al. Non-invasive identification of a high risk subset of patients with acute inferior myocardial infarction. Am f Cardiol 1980;46:915-21.

- Salcedo JR, Baird MG, Chambers RJ, Beanlands DS. Significance of reciprocal ST segment depression in anterior precordial leads in acute inferior myocardial infarction: concomitant left anterior descending disease ? Am f Cardiol $1981 ; 48: 1003-8$.

5 Goldberg HL, Borer JS, Jacobstein JG, Kluger J, Scheidt SS, Alonso DR. Anterior ST segment depression in acute inferior myocardial infarction indicator of posterolateral infarction. Am f Cardiol 1981;48:1009-15.

- Miller RR, DeMaria AN, Vismara LA, et al. Chronic stable inferior myocardial infarction: unsuspected harbinger of high-risk proximal left coronary arterial obstruction amenable to surgical revascularisation. Am $\mathcal{F}$ Cardiol 1977;39:954-60.

7 Schuster EH, Bulkley BH. Ischemia at a distance after acute myocardial infarction: a cause of early post-infarction angina. Circulation $1980 ; 62$ : 509-15.
${ }^{8}$ Dunn RF, Kelly DT, Sadick N, Uren R. Multivessel coronary artery spasm. Circulation 1979;60:451-5.

- Bertrand ME, Lablanche JM, Tilmant PY, Thieuleux FA, Deforge MG, Chahine RA. The provocation of coronary arterial spasm in patients with recent transmural myocardial infarction. Eur Heart $\mathcal{f}$ (in press).

${ }^{10}$ Griffith LC, Grundwald L, Achuff SC. Electrocardiographic changes in single-vessel disease [Abstract]. Circulation 1978;58 suppl 2:238.

1 Prinzmetal M, Ekmekci A, Toyoshima H, Kwoczynski JK. Angina pectoris. III. Demonstration of a chemical origin of ST depression in classical angina pectoris, its variant form, early myocardial infarction and some non-cardiac conditions. Am $\mathcal{f}$ Cardiol $1959 ; 3: 276-93$.

12 Gibson RG, Crampton RS, Watson DD, et al. Precordial ST segment depression during acute inferior myocardial infarction: clinical, scintigraphic and angiographic correlations. Circulation 1982;66:732-41.

13 Gelman JS, Saltups A. Precordial ST segment depression in patients with inferior myocardial infarction: clinical implications. Br Heart $\mathcal{F}$ 1982; 48:560-5.

14 Croft $\mathrm{CH}$, Woodward $\mathrm{W}$, Nicod $\mathrm{P}$, et al. Clinical implications of anterior ST segment depression in patients with acute inferior myocardial infarction. Am $\mathcal{F}$ Cardiol $1982 ; 50: 428-36$.

(Accepted 13 May 1983)

\title{
Initial experience with indium-111 autologous leucocyte imaging in patients with acute pancreatitis
}

\author{
J R ANDERSON, R A J SPENCE, J D LAIRD, W R FERGUSON, T L KENNEDY
}

\begin{abstract}
Indium-111 labelled autologous leucocyte imaging was used to assess severity in 13 patients with acute pancreatitis. All three patients with severe disease as judged by a prognostic factor grading system had a positive result on imaging. A fourth patient with mild disease as judged by prognostic factors had a positive imaging result and 14 days later developed a pseudocyst. There were no false positive or false negative scans. Evidence from three patients suggested that a positive "11n-leucocyte imaging result implies substantial fat necrosis.

In this study imaging was as accurate as prognostic factor grading. The technique may be a useful method of separating mild from severe acute pancreatitis.
\end{abstract}

\section{Introduction}

Indium-111 labelled autologous leucocyte imaging is now an established method for locating infection, both within the abdomen and at other sites. ${ }^{1-3}$ Recent reports suggest that it also accurately assesses the extent of colonic inflammatory bowel disease. ${ }^{45}$ To date there is only one report of its use in acute pancreatitis-namely, in patients being investigated for suspected pancreatic abscesses. ${ }^{6}$ We report our experience of the use of "11 In imaging in patients with acute pancreatitis.
Royal Victoria Hospital, Belfast, Northern Ireland

J R ANDERSON, MB, FRCS, senior surgical registrar

R A J SPENCE, MB, FRCS, research fellow

J D LAIRD, MB, FRCR, consultant radiologist

W R FERGUSON, MSC, PHD, senior physicist

T L KENNEDY, MS, FRCS, consultant surgeon

Correspondence to: $\mathrm{Mr}$ J R Anderson, Department of Surgery, Royal Victoria Hospital, Belfast BT12 6BA, Northern Ireland.

\section{Patients and methods}

Thirteen patients were studied prospectively. Seven were women and six men, and their average age was 56 years (range 19-86). The diagnosis of acute pancreatitis was based on the clinical presentation together with a serum amylase activity greater than $1000 \mathrm{IU} / 1$ (mean value on admission $3257 \mathrm{IU} / \mathrm{l}$, range 1050-8100 IU/1). Serum amylase measurements were recorded daily until they had returned to normal, and thereafter they were recorded every three days until discharge. In four patients the serum amylase activity had returned to normal three days after admission, in three patients by the fourth day, in a further four patients by day 5 , and in the final two patients by day 7 .

The severity of the initial attack was assessed using the prognostic factor grading system described by Imrie et al, ${ }^{7}$ as modified for gall stone associated pancreatitis. ${ }^{8}$ Two patients developed hypocalcaemia, with serum calcium concentrations falling below $2.0 \mathrm{mmol} / 1(8.0 \mathrm{mg} /$ $100 \mathrm{ml}$ ). Ultrasound examinations were performed in 11 of the patients within five days of admission.

For each patient autologous leucocytes labelled with ${ }^{11}$ In were prepared using ${ }^{11}$ In-hydroxyquinoline (oxine) solution (Amersham International IN 15P), the labelling dose being in the range 10-20 $\mathrm{MBg}(270-540 \mu \mathrm{Ci})$. A mean labelling efficiency of $78.5 \%$ (range $62-95^{\circ}$ ) was achieved for all patients studied. In all cases at least one set of images was obtained within 24 hours of administration of the labelled leucocytes. Imaging was performed with the patients supine using a large field of view gammacamera fitted with a parallel hole medium energy collimator and with analyser windows set to accept the 171 and $247 \mathrm{keV}$ gamma photons from ${ }^{111}$ In. At least 400000 counts per image were collected. Imaging was performed within three days of admission in 12 patients and on day 7 after diagnosis in the remaining patient.

\section{Results}

The table shows the aetiology and severity of the condition in the 13 patients and compares the results of ${ }^{111}$ In-leucocyte imaging and abdominal ultrasound. Three patients had severe pancreatitis, and all three had positive ${ }^{111}$ In-leucocyte imaging results (fig 1). A fourth patient (case 8), judged on prognostic factors to have mild disease, had a positive result on "1"In-leucocyte imaging (fig 2 ). This patient developed a pseudocyst 14 days after admission.

The remaining nine patients all had mild pancreatitis on prognostic 
Aetiology and severity compared with ultrasound and leucocyte imaging in patients studied prospectively

\begin{tabular}{|c|c|c|c|c|c|c|}
\hline Case No & $\begin{array}{c}\text { Age } \\
\text { and sex }\end{array}$ & Aetiology & Severity & $\begin{array}{c}\text { Results of } \\
\text { white cell study }\end{array}$ & $\begin{array}{c}\text { Results of } \\
\text { pancreatic ultrasound }\end{array}$ & Complications \\
\hline $\begin{array}{r}1 \\
2 \\
3 \\
4 \\
5 \\
6 \\
7 \\
8 \\
9 \\
10 \\
11 \\
12 \\
13\end{array}$ & $\begin{array}{l}83 \mathrm{M} \\
79 \mathrm{~F} \\
53 \mathrm{~F} \\
20 \mathrm{M} \\
50 \mathrm{M} \\
19 \mathrm{~F} \\
86 \mathrm{~F} \\
69 \mathrm{M} \\
23 \mathrm{M} \\
56 \mathrm{~F} \\
82 \mathrm{~F} \\
42 \mathrm{~F} \\
62 \mathrm{M}\end{array}$ & $\begin{array}{l}\text { Gall stones } \\
\text { Gall stones } \\
\text { Unknown } \\
\text { Alcohol } \\
\text { Alcohol } \\
\text { Gall stones } \\
\text { Gall stones } \\
\text { Gall stones } \\
\text { Alcohol } \\
\text { Gall stones } \\
\text { Unknown } \\
\text { Gall stones } \\
\text { Alcohol }\end{array}$ & $\begin{array}{l}\text { Mild } \\
\text { Severe } \\
\text { Mild } \\
\text { Mild } \\
\text { Mild } \\
\text { Mild } \\
\text { Mild } \\
\text { Mild } \\
\text { Mild } \\
\text { Severe } \\
\text { Mild } \\
\text { Mild } \\
\text { Severe }\end{array}$ & $\begin{array}{l}\text { Negative } \\
\text { Positive } \\
\text { Negative } \\
\text { Negative } \\
\text { Negative } \\
\text { Negative } \\
\text { Negative } \\
\text { Positive } \\
\text { Negative } \\
\text { Positive } \\
\text { Negative } \\
\text { Negative } \\
\text { Positive }\end{array}$ & $\begin{array}{l}\text { Not seen* } \\
\text { Swelling* } \\
\text { Swelling } \\
\text { Normal } \\
\text { Swelling } \\
\text { Normal* }^{*} \\
\text { Normal* }^{*} \\
\text { Swelling* } \\
\text { Not done'† }^{*} \text { Swelling* }^{*} \\
\text { Swelling } \\
\text { Not doneł } \\
\text { Normal }\end{array}$ & $\begin{array}{c}\bar{z} \\
\bar{z} \\
\bar{z} \\
\text { Pseudocyst } \\
\bar{z} \\
\text { Acute renal failure }\end{array}$ \\
\hline
\end{tabular}

*Ultrasound scan showed gall stones. †Recent outpatient oral cholecystogram normal. †Recent outpatient oral cholecystogram showed stones.

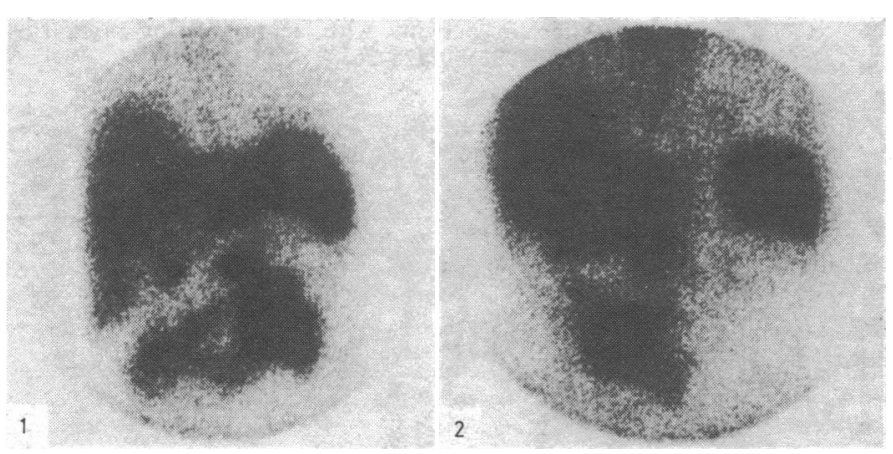

FIG 1 -Case 10 . Woman aged 56 with severe gall stone associated pancreatitis. Anterior view, showing extensive areas of uptake in subhepatic area and central abdomen. At cholecystectomy fat necrosis found around duodenum.

FIG 2-Case 8. Man aged 69 with clinically mild pancreatitis. Anterior view, showing uptake in central abdomen and subhepatic area. Patient developed pseudocyst.

criteria. None had a positive leucocyte study result, all settled without complication, and all were discharged from hospital within 14 days of admission.

\section{Discussion}

Assessment of the severity of an attack of acute pancreatitis is important to identify those patients who have the haemorrhagic form of the disease, with its high mortality and morbidity. The presenting clinical features are a poor guide to severity. ${ }^{9}$ Hypocalcaemia, ${ }^{10}$ a raised fibrinogen concentration, ${ }^{11}$ complement activation, ${ }^{12}$ and peritoneal lavage ${ }^{13}$ have all been shown to be of value in assessing the severity of pancreatitis. Ranson et $a l^{14}$ and Imrie $e t a l^{7}$ based their assessment of severity on multiple prognostic factors; the criteria of Imrie et al have become widely accepted in Britain. We compared severity of the disease as judged by Imrie's modified criteria ${ }^{8}$ with ${ }^{111}$ Inleucocyte imaging. Three patients with severe disease had positive results. A fourth patient with mild disease on the basis of the prognostic factors had a positive ${ }^{111}$ In imaging result three days after admission and later developed a pseudocyst.

Grey scale ultrasound is a useful method of detecting gall stones but provides no additional information in the early stages of the disease. ${ }^{15}$ In our study six patients with gall stone associated pancreatitis had their stones detected by this method.

One major problem with any comparative study is the definition of mild and severe disease in the presence of a wide range of clinical manifestations. Any definition is arbitrary but the aim of prediction in acute pancreatitis is to identify those patients who will develop complications or who will have a protracted clinical course. By using the clinical criteria suggested by McMahon et al ${ }^{13}$-namely, more than 14 days in hospital or the presence of a severe complication-all four patients with positive ${ }^{111}$ In imaging results had severe disease. No false positive or false negative ${ }^{111}$ In images were found compared with a $53 \%$ false positive rate and a $23 \%$ false negative rate for $\Rightarrow$ multifactorial assessment in one recent study ${ }^{11}$; the numbers in our study, however, were small.

What does a positive ${ }^{111}$ In imaging result mean ? In case $13 \stackrel{\mathrm{\omega}}{\mathrm{W}}$ computed tomography was carried out 24 hours after radio- $\frac{3}{3}$ nuclide imaging and showed the presence of extensive fat necrosis in areas corresponding to those showing increased $\infty$ leucocyte uptake on the indium image. Extensive fat necrosis o was also noted in cases 8 and 10 at subsequent cholecystectomy. We believe that a positive "'In imaging result implies severe fat necrosis.

From our initial experience it seems that ${ }^{111}$ In-leucocyte 0 imaging is a simple, non-invasive technique for assessing severity ${ }_{\omega}$ early in the course of acute pancreatitis. Its accuracy is similar $\omega$ to that of prognostic factor grading. Further studies using serial $\mathbb{D}$ imaging are needed to define more precisely the fate of fat $\stackrel{\vec{\Phi}}{\vec{D}}$ necrosis in acute pancreatitis.

We thank Mr G W Johnston, Mr W Wilson, Mr S T D McKelvey, and Professor T G Parks for allowing us to study patients under their $\infty$ care, and Miss $S$ Campbell for typing the manuscript.

\section{References} McDougall IR, Baumert JE, Lantieri RL. Evaluation of ${ }^{111}$ In leucocyte $\frac{\varrho}{\mathbb{Q}}$
whole body scanning. $A \mathcal{Q}$. $1979 ; 133: 849-54$.

2 Carroll B, Silverman PM, Goodwin DA, McDougall IR. Ultrasonography $\vec{\overrightarrow{ }}$ and indium 111 white blood cell scanning for the detection of intra- $\frac{0}{3}$ abdominal abscesses. Radiology 1981 ;140:155-60.

${ }^{3}$ Ascher NL, Forstrom L, Simmons RL. Radiolabelled autologous leucocyte scanning in abscess detection. World f Surg 1980;4:395-402.

4 Segal AW, Ensell J, Munro JM, Sarner M. Indium-111 tagged leucocytes in the diagnosis of inflammatory bowel disease. Lancet $1981 ; \mathrm{ii}: 230-2$.

5 Saverymuttu SH, Peters AM, Hodgson HJ, Chadwick VS, Lavender JP. Indium-111 autologous leucocyte scanning: comparison with radiology oे for imaging the colon in inflammatory bowel disease. Br Med F 1982; $285: 255-7$.

${ }^{6}$ Fawcett HD, Lin MS, Goodwin DA. Indium-111 labelled leucocyte imaging in acute pancreatitis with suspected complicating abscess. Dig Dis Sci 1979;24:872-975.

7 Imrie CW, Benjamin IS, Ferguson JC, et al. A single centre double-blind trial of Trasylol therapy in primary acute pancreatitis. Br f Surg 1978; N

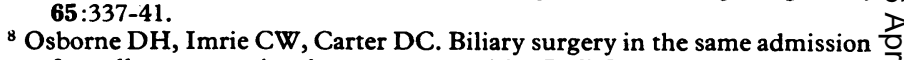
for gallstone-associated acute pancreatitis. Br $\mathcal{F}$ Surg 1981 ;68:758-61.

- Storck G, Petterson G, Edlund Y. A study of autopsies upon 116 patients N with acute pancreatitis. Surg Gynecol Obstet 1976;143:241-5.

10 McMahon MJ, Woodhead JS, Hayward RD. The nature of hypocalcaemia in acute pancreatitis. $B r \mathcal{F}$ Surg 1978;65:216-8.

11 Berry AR, Taylor TV, Davies GC. Diagnostic tests and prognostic indicators in acute pancreatitis. $\mathcal{F} R$ Coll Surg Edinb 1982;27:345-52.

12 Galloway DJ, Murray WR, Foulis AK, et al. Endotoxaemia and comple- \& ment activation in acute pancreatitis. Br $\mathcal{F}$ Surg 1981;68:360.

13 McMahon MJ, Playforth MJ, Pickford IR. A comparative study of $\frac{T}{T}$ methods for the prediction of severity of attacks of acute pancreatitis. $\frac{\mathrm{O}}{\mathrm{D}}$ Br F Surg 1980;67:22-5.

14 Ranson JHC, Rifkind KM, Roses DF, et al. Prognostic signs and the role of operative management in acute pancreatitis. Surg Gynecol Obstet 1974;139:69-81.

15 McKay AJ, Imrie CW, O'Neill J, Duncan JG. Is an early ultrasound scan of value in acute pancreatitis ? BrF Surg 1982;69:369-72.

(Accepted 21 fune 1983) 